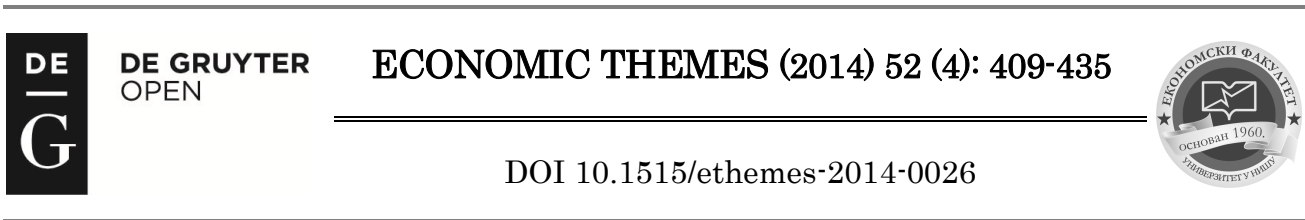

\title{
THE ROLE OF ICT AND THE INTERNET IN THE DEVELOPMENT OF FRANCHISE SYSTEMS
}

\author{
Suzana Stefanović \\ University of Niš, Faculty of Economics, Serbia \\ $\bowtie$ suzana.stefanovic@eknfak.ni.ac.rs \\ Milica Stanković \\ Higher Business School, Novi Sad, Serbia \\ $\bowtie$ milica.stankovic.vps@gmail.com
}

UDC

004:007:

339.187.44

Original

scientific

paper

Received:

16.07.2014

Accepted:

29.12.2014

\begin{abstract}
Franchising is a business format which is becoming a global phenomenon in the contemporary business. Franchise systems extensively use modern information and communication technology (ICT) to enhance communication among franchisors and franchisees, and to provide interaction with end users. The aim of the paper is to highlight the importance of using the modern technology in franchise systems globally and need for more intensive use of ICT in our country and in neighboring countries, based on the comparative analysis of using the ICT and Internet in developed and less developed economies. The research was conducted through a comprehensive on-line analysis of franchisors' web sites. In this paper, it is analyzed whether there is a connection between the franchisors and franchisees linking through web site and the number of given franchise. Correlation analysis showed a statistically significant strong positive correlation between the use of the web site for linking franchisors and their franchisees and the number of franchise units. It can be concluded that less use of modern technology and the Internet in developing countries affects the slower expansion of the franchise units network than in developed countries where the use of ICT and the Internet is at a much higher level.
\end{abstract}

Keywords: franchising, information and communication technology (ICT), web site, Internet, franchise units 


\section{Introduction}

Franchising experiences a bloom and is considered a form of business that has a growing impact on the global economy. Due to the increased popularity of franchising as a mechanism of economic growth over the last forty years, a number of researchers in different social sciences and humanities put their focus on the analysis of this area. In economic practice, there is a noticeable tendency of constant development and improvement of the existing franchise systems, considering the great importance that these systems have for employment, GDP growth, and overall economic growth. The concept of franchising is attractive as a model of self-employment, particularly due to the appearance of a downsizing in large companies affected by the crisis. Although franchising, as a concept by its very nature, is a global phenomenon, there are a number of contemporary trends that should be addressed within the framework of the development of a national franchise system. Differently from developed market economies, there is still a noticeable lack of academic research in the field of franchising in Serbia, especially regarding the current trends in this field. The use of modern information and communication technologies (ICT) affects almost every aspect of modern society, both in Serbia and worldwide. In this regard, it is especially important to mention that franchise organizations increasingly opt for intensive use of modern technology in their business processes, which leads to a series of changes in the relationship between the participants in a franchise system. The use of modern ICT in the franchise systems increases the quantity, quality and frequency of information exchange between participants and causes growth of franchisor's and franchisee's informational power. Therefore, the aim of this study is to highlight the importance and possibilities of using modern information and communication technologies in the franchise systems on a global level, as well as to emphasize the need for more intensive use of ICT in Serbia and the surrounding countries based on a comparative analysis of the use of ICT and the Internet in less developed economies and developed market economies. The starting assumption of the study is that the use of ICT and the Internet in the development of franchise systems in less developed economies lag behind the use in the developed market economies, and that there is a different purpose and usage of ICT in these countries.

Namely, the current trends in the development of franchising are primarily related to the use of information and communication technology, which has experienced expansion on a global level, while its use is still insufficiently present in franchise systems in the less developed economies. It is assumed that ICT is used to a greater extent by the franchisor in developed countries for the establishment of relations with franchisees, and the intensity of the use of ICT in establishing a relationship with end users is higher in developed countries than in Serbia and Croatia, for example. Also, one of the assumptions in the paper is that the use of ICT by the franchisor in less developed economies is 
more focused on providing information to prospective franchisees and end customers rather than on providing services and business networking. The last but not least, is the assumption that linking franchisees with the franchisor through the website affects the number of given franchise units and, consequently, the development of the franchise systems. The authors will try to prove this assumptions by using methods of statistical analysis. In relation to these assumptions, the main research questions that the authors will try to answer in this paper are: first, what is the extent to which the use of ICT and the Internet leads in franchise systems in developed market economies such as Australia, the U.S. and UK in comparation with under-developed market economies, such as Serbia and Croatia, and in which fields the biggest difference when it comes to the use of modern technological solutions is observed? Second, to what degree franchisors in the analyzed countries use Internet technology to establish relationships with franchisees? Third, to what extent ICT and Internet are used by franchisors to establish a relationship with the end users? Fourth, what kind of informations franchisors provide to franchisees and end users in less developed countries? Fifth, is there a statistically significant relationship between the use of franchisors' website to connect with franchisees and increase in the number of franchise units?

Based on the analysis of using the ICT by the selected franchise systems in Serbia, Croatia, Australia, U.S. and UK, authors will try, in order to answer to the research questions, to confirm the initial hypothesis and obtain relevant conclusions and implications for development of the theory and practice of franchising in Serbia, using the methods of comparative and statistical analysis.

The paper is structured in the way that the first part indicates the characteristics of franchising as a business model and the importance of modern information and communication technologies in franchise systems worldwide. In the second part of the paper, we analyze the use of ICT and the Internet within selected franchising systems in Serbia, Croatia, Australia, U.S. and UK, and we come to relevant results on the basis of comparative analysis. The third part of the paper refers to the importance of using ICT for connecting participants in the franchise systems and focuses on the correlation analysis of the relationship between the use of selected franchisors' websites from mentioned countries to connect with franchisees and the number of given franchise units.

\section{The Importance of Using the Modern Technology for the Development of the Franchise Systems}

In recent decades the number of franchises in the world has increased significantly, due to the fact that franchising offers better financial results and a greater chance of survival than alternative forms of entering the business (Nijmeijer, et al., 2013). Franchising is a highly standardized concept of 
collaboration that symbolically represents the "tailored suit made to measure franchise owners" (Ćuzović, 2010). Franchising involves the transfer of an existing successful business model to another company upon paying the appropriate fee (engl. royality). Franchisees provide financial compensation for franchise and respects contractual business standards and the franchisor in return gives them business name and model. The largest number of studies dealing with franchising are conducted in the United States, although there is growing interest in all developed countries across Europe. In Serbia, there is still a relatively small number of studies dealing with the topic of franchising. Internationalization of franchising systems in Serbia is not yet sufficiently developed or researched field, despite the fact that franchising is one of the business forms that allows significantly intensify expansion both on domestic and on international level in relation to other business forms (Stefanović and Stanković, 2013).

Franchising becomes one of the most popular methods for business growth, especially if the goal is international expansion and growth (Duckett, 2008). Franchise business concept is most common in the USA, where a large number of companies operate according to this system. Australia is also one of the countries in which the franchise is very popular business model. The rate of growth in the number of franchise units in Australia was 14\% from 2002 to 2004. In fact, the Australian franchising sector has three times as many franchisees per capita than more mature franchise sector in the USA (Merrilees and Frazer, 2006). Franchising is also very present in Europe. In the UK, the number of franchise systems has a constant tendency to increase. During the 2002, 29 new franchises were developed and the total number of franchises grew to 929 . The total number of franchise units was increased by $4 \%$ as compared to 2011, so in the 2012 there were 40,100 business units (British Franchise Association, 2013). Among all developing countries, franchising is the most developed in Hungary and from neighboring countries in the Croatia. In Hungary, there are about 400 franchise chains, while in Croatia currently exist about 120 franchisors, one quarter of them are domestic (Centar za fransizing, Privredna komora Srbije, 2013). The franchise business model is still developing in Serbia. There is a large number of foreign franchises operating in Serbia, but the number of domestic franchise systems increases annually too. The real expansion of a franchise concept in Serbia is expected in the following years. Awareness of the importance of a franchise system in Serbia is still much lower than in developed countries. That is why it is necessary to intensify popularization of the franchising concept in Serbia, considering the number of benefits that are achieved using this system (for details see: Stefanović and Stanković, 2013).

By entering the world of franchising, one gets a finished business model that should be applied, and tested model for attracting customers, advertising methods and a stable market (Alpeza and Erceg, 2012). Also, in the case of 
franchising the risk is reduced than in starting an independent business. There is no need for market research, because the franchisor has already done that. Franchisor provides support to franchisees, but retains some control over the way they operate. In return, the franchisee pays to franchisor an initial cost and agreed fee for using the franchise (ibid). It can be said that the success of the franchise systems largely depends on the franchisor-franchisees relationship. Franchisor and franchisees need to work together as a team for the purpose of achieving common goals that are placed above individual interests. Therefore, factors such as trust, cooperation, commitment and loyalty are crucial for a good franchise relations.

The use of modern technology in franchise systems is of great importance in the contemporary global environment. This is one of new trends in the development of franchising in Serbia and worldwide. Certainly, franchise concepts in developed countries accept innovations faster than franchise systems in less developed countries. Accordingly, it is necessary to point out the importance of the application of modern information and communication technologies (ICT) in the development of franchising and benefits that this type of innovation can bring in the field of franchising. In order to assist the development of franchising, it is necessary for ICT to: be affordable and easily accessible, to save time and money, and to create value for customers and franchisors (Rao and Frazer, 2005). It is very important to include franchisees in technological innovation and development, so that franchisors can apply innovative solutions truly successfully. When implementing ICT, it is always the best to create a common process in which franchisor and franchisees will work together, not only to create, but also to implement some technological solutions and to continue improving them.

The advantages provided by use of the Internet in B2B (Business-toBusiness) market, whose integral part are franchises, are listed in numerous studies, which will be discussed below. The benefits are primarily related to better communication with suppliers and franchises. Internet is considered as a new communication medium, as it enhances business communication through the efficient and effective search and information exchange (Zettelmeyer, 2000) and improvement of connectivity and interactivity (Dutta and Biren, 2001). Electronic communication within the franchise systems will provide all that is necessary for franchisees that can be electronically delivered with small or negligible costs in real time. For modern customers, the fact that the company does not have a website, is as shocking as when they get to the cash register in the store and realize that they can only pay in cash (Franson and DeSmith, 2005). Today, ICT offers a solution for all needs of modern business, from the online advertising to the accounting and monitoring employees' performance. There are online services that help thousands of franchisees to strengthen relationships with customers and achieve real business results, such as e-mail marketing and online 
surveys or polls. Franchise deliver their advertising messages to target customers who are on e-mail lists companies quickly, easily and efficiently, combining the simplicity of e-mail with the possibilities of the Internet. The research that provides answers to the questions whether the franchise knows what their customers think about the latest offering product, whether the level of provided services is in accordance with customer expectations and so on, can be carried out by using on-line survey (O’Brien, 2008).

Initially, the primary purpose of using the website by the franchisor was to promote the franchise system to potential franchisees (Martin, 1999). In recent years, it is common for franchisors to adopt a dual marketing approach when designing their websites (Love, 1998). Dual marketing approach means that franchisors try to establish communication with franchisees, as well as with end customers through Internet based technology. Information is provided in real time, for all members of the franchise system, through the Internet. In this way, franchisees are given the opportunity to share experiences and to communicate more effectively with each other about business strategies. For example, Planet Smoothie franchisees communicate with other franchisees over the Internet and discuss in the so-called chat rooms (discussion which is achieved via the Internet) on the issues that are the focus of their interest (Love, 1998).

E-mail, chat rooms and web-based video conferencing allow to franchise partners more options for easy documents and opinions exchange, thereby strengthening the relationship (Boyle and Alwitt, 1999). In addition to spreading information, Internet based technology can be used for activities such as marketing in real time, providing so-called "knowledge reservoir", coordination and conflict resolution within the franchise systems (Vilchis, 2001). Monitoring and controlling franchisees by the franchisors are facilitated by Internet based technologies. Using website strengthens B2B (Business-toBusiness) and B2C (Business-to-Customer) relationship through allowing companies to use multimedia recordings about products and services, such as video presentations about products and services. Information on websites can be updated quickly and continuously and are always available to consumers and business partners (Biland, 2000).

Franchisor's website plays an important role in the "recruitment" of new franchisee and becomes the main source of their questions and requests. Internet enables franchisors to conduct on-line screening of candidates, potential franchisees (Fisher and Mullin, 2000). In fact, web site may contains information such as an overview of franchise programs, franchisee's experiences and details about opportunities that franchise provides. Some franchisor's web sites contain information about the required initial capital that potential franchisees have to invest, as well as the amount of the fee (engl. royality). All this makes the Internet a valuable communication medium that provides effectiveness to the franchisor in terms of finding potential franchisees. 
The use of the Internet in the franchise systems enables the franchisor to collect franchisee's fees through electronic transfer of money or on-line credit card payments. Websites may allow franchisees to purchase on-line items for marketing support, including promotional materials, CD for technical support and training, business uniforms, etc. (Rogers, et al., 2007).

Direct marketing costs for a franchise system can be reduced by using the Internet. Costs are reduced through the replacement of numerous brochures, letters, and notes that members of the franchise sent by mail or fax, while they were not able to do it electronically. Franchisor's virtual brochure enables reducing costs and increasing effectiveness (Franklin, 2005). Electronic brochure may contain director's video messages and details about the franchise, as well as virtual tours through existing franchise units. If well designed, virtual brochure should provide prospective franchisees all the necessary information to make good decisions about potential investments. Brochure can ensure a video experience of current franchisees and other important information about key aspects of the business. In this way, we can say that virtual brochure enables spending a "virtual day" in the franchise system (ibid).

Nowadays, most websites contain detailed product descriptions and guidelines for users to locate franchise units in its vicinity more easily. On-line access will improve consumer awareness about a particular franchise concept, which ultimately can lead to increased sales in the franchise units. It can be argued that on-line sales promotional activities are partially franchisor's efforts to increase overall franchisee's sales. It is important to mention that many websites contain a feedback form through which customers can ask questions and leave comments. In this manner, members of the franchise systems can respond to their customers faster and provide better service. Customer service is no longer timed. The company may receive customer's questions or requirements on-line and provide detailed answers 24 hours a day. In addition, customers can find out information about products and services on-line rather than waiting for sales representatives. For example, Federal Express gives customers the ability to track their packages through their website. This online service allows company's customers to obtain accurate information about where their packages are and when they will be delivered (Lancioni, et al., 2000).

Other advantages of the Internet for franchise systems relate to profitability, reducing costs and increasing revenue. Many companies benefit from using Internet based technologies in terms of savings on operational tasks, such as ordering, receiving, invoice tracking and payment, due to the integration effects of electronic technology. Federal Express has announced that their on-line services help companies saving between 4 and 6 million annually for expenditures of monitoring (Gilbert, 2001). In addition to reducing operating costs, marketing communications costs can also be directly reduced through using the Internet as an important communication medium. It can be used to 
generate revenue by increasing speed of delivering products to market and reducing barriers to entry into the global market (Rao and Frazer, 2005). Using the Internet improves operational efficiency through automated purchasing, reducing errors and time to complete business transactions and increasing flexibility and speed of response. Internet enables companies to manage their supply chain efficiently, in an integrated manner, through the development of closer ties with their business partners, which ultimately provides upgraded response to demands of end customers (Kothandaraman and Wilson, 2001). Electronic Data Interchange (EDI) and Electronic Funds Transfer (EFT) improve supply chain management, which allows faster and more accurate transactions (Griffith and Palmer, 1999).

The rapid growth in popularity of the Internet as a medium for an easier getting to customers around the world, has led to the fact that e-commerce has become another important area of research in recent years. Electronic commerce can be defined as the electronicl exchange of information, goods, services and payments (Rogers, et al., 2007). This definition can be extended to creating and maintaining relations through the web. Electronic commerce provides a range of opportunities for franchise systems, but we should mention some of the limitations. Primarily, consumers benefit in terms of increased availability and ease of access to information and opportunity to see products on-line and to make purchasing decisions based on large-scale information quickly and easily. Also, Internet sales have advantages over traditional in terms of wider reach, unlimited working hours and high degree of flexibility (Enders and Jelassi, 2000). Some authors point out that franchise systems are especially suitable for e-commerce due to the brand recognition. Franchisors must take into account the environment in which they operate and franchisees' willingness to cooperate in the development of electronic commerce. The most problematic aspects of the relationship between franchise and e-commerce are legal implications of a franchise business over the Internet (Gotsopoulou, 2000; Trice, 2001). Like any other company that operates in cyberspace, the franchise company must be aware of the development of legislation that regulates electronic commerce in general, including legislation related to privacy, copyright protection etc. (Watson et al., 2002). However, the international nature of franchising puts this business form in an unfavorable position compared to other business models when it comes to online activities. For example, the main reason that some franchisors have a website is to provide informations about franchises that are available, but at the same time they should take into account the differences in legislation in this area in different countries (Fisher and Mullin, 2000). By selling products on-line, franchisors may disturb cross-border competition laws or may violate their own franchise agreements in respect of territorial rights (Floriani and Lindsey, 2001). The fact that the legislation related to electronic commerce is still developing and that a large number of franchise agreements were signed when the Internet was still in its infancy highlights this problem. 
It is emphasized that e-commerce can, theoretically speaking, eliminate the need for franchising, considering that in this case, end customers can order products and pay on-line instead of going to the nearest franchise units (Plave and Amolsch, 2000). If most of goods can be purchased online, the need for the presence of goods in traditional franchise units will be lower, and it will reduce the attractiveness of franchising as a cost-effective way of doing business. Hereby, franchisees may feel aggrieved because franchisors may reduce sales in traditional franchise units via e-commerce through the website.

Sometimes franchisors provide so called "reverse fee" to franchisees in exchange for the loss of revenue due to Internet sales through the franchisor's website, but it cannot always solve the problem (Dixon and Quinn, 2004). Lower costs of on-line retailing compared to traditional retail would contribute that companies expand their business quickly and easily without using franchising as a business system. On the other hand, the very nature of certain products and services may contribute to the fact that they cannot be sold online, which speaks in favor of the franchise concept (ibid). There are four ways for organizing on-line sales by franchisors (Plave and Amolsch, 2000):

- Franchisor performs the entire on-line business and collects all the profit,

- Franchisor performs the entire on-line business, but shares the profit with franchisees,

- Franchisor performs the entire on-line business with the responsibility of the franchisee to fulfill orders and participate in profit,

- Franchisee performs on-line business independently and pays adequate compensation to the franchisor.

If franchise companies want to remain competitive on the market, the website's presence becomes imperative. The franchisor's websites are quite heterogeneous in terms of functionality and content: some offer limited services with content that is rarely updated, while others are characterized by a high degree of technical sophistication and provision of a wide range of services. It is essential for franchisors and franchisees to establish a presence on the Internet in order to build and strengthen their brand, keeping in mind that a brand is a key element of the franchise (MSA Worldwide, 2011). Franchisor's websites should provide updated information about products and services that may be of importance to end customers, as well as to franchisees. Through its website, franchisor may attract potential franchisees by pointing out the possibility to join the franchise. Often, francisor's web sites contain information about available products and services, discounts, special offers, awards, and staff information. Customers prefer updated web sites, especially if franchise companies timely inform them about sales, new products and offer a wide range of other useful information via websites. There are several options for the presence of franchise company through a website (MSA Worldwide, 2011): 
- Franchisor develops its website on which are located links to the franchisees' pages. For example, if a franchisor's website is: www.davis.ca, then the franchisee's website should be: www.davis.ca/toronto. For most franchisors and franchisees, the best option is that franchisors centrally develop and maintain websites for all of its location, because it provides the best control over the format and content of the franchisee's website. Through the development and maintenance of websites for the entire system, franchisors and franchisees can be sure that each website will have a consistent look and brand consistency will be ensured. Websites will include information about each location and franchisees will be able to update their information periodically by forwarding changes to franchisors who will then publish them on the website. Consumers will be able to access the franchisee's website through the links on the franchisor's website. Franchisor may discourage franchisees from opening their own websites in an effort to preserve the uniformity of the brand, as it is crucial for the franchise (Perrigot and Pénard, 2012). This method ensures unity and control without leaving customers the dilemma whether the franchisee is a part of a larger integrated system. This also gives the franchisor a significant advantage if the franchisee leaves the franchise system, because the franchisor will have the option to simply turn off the franchisee's website (Rogers and Bennett, 2005). One of the negative aspects associated with the development of websites by the franchisor is that setting up and maintaining the web site is quite expensive. In addition, franchisees often want to personalize and localize the content on their web pages to a greater extent than franchisor allows. Finally, due to the volume of changes on the franchisee's web sites, franchisors will be able to make changes to the web site slower in relation to modification by each franchisee individually.

- Franchisees develop an independent websites without specific instructions from franchisors. If franchisors do not provide instructions for setting up a franchisees' web site, franchisees develop separate websites for their business. In some franchise systems, the lack of initiative by the franchisor in creating websites, leads franchisees to independently start to garner their customers over the Internet. Websites developed by franchisees' without any franchisor's control are the least attractive option for franchisor for several reasons. One reason is that such a presence on the web can make it difficult for consumers and potential franchisees to find franchisor's website because browsers can direct individuals to franchisees' websites. Also, there is the potential for dilution of the message, with different content on the franchisor's and franchisee's websites. If franchisor is not careful, independent franchisee's web sites may contain information which is a business secret. Also, the use of information about consumers could cause problems compromising privacy rights. Independent web sites may contain inappropriate information (e.g. promotion competitor's products) or links to 
auction websites and websites with discounts. If franchisees set up information about prices of products or services on his own independent website which are different than prices of other franchisees, there is a risk that franchisees become competitive. Thus, independent websites that are developed without any guidelines and controls can be problematic both for franchisors and franchisees (Rogers and Bennett, 2005).

- Franchisees develop their own websites, but on the basis of specific guidelines and control of the franchisor. In this way, many problems of independent websites are solved and there are a lot of benefits for both franchisees and franchisor. However, there may be some problems. Given that the franchisor must supervise a number of franchisees' websites, there are high costs of monitoring changes at every website. Personalized websites by franchisees, even with the use of a single template, can still lead to the violation of brand consistency (ibid).

Different technologies are being used increasingly for faster, more efficient and more effective communication. The following tools can be used effectively to improve business processes and to create a stronger franchise system: on-line meetings, Voice Over Internet Protocol (VoIP), Virtual Private Networks (VPN), discussion groups and forums (Bridge, 2005), as well as corporate blogs.

- On-line meetings. For franchisors, company's success depends on the strength of their communication networks that connect them with franchisees. On-line meetings are a tool that can help to save time and money and to facilitate real-time communication while ensuring complete confidentiality of conversations and data transfer. Participants in the franchising systems have access to various interactive features and highquality audio and video recordings. Franchisees are increasingly using this technology to train employees. On-line training and seminars are powerful tools that can provide a sense similar to face-to-face communication, with lower costs and less travel. The so-called "webinars" (from English words web and seminars) are an effective tools, particularly for a growing franchise network with a large number of franchisees which operate in different countries (Spindel, 2008). Internally produced "webinar" recordings can help provide information to franchisees about changes, operating procedures or adequate training.

- Voice Over Internet Protocol (VoIP). VoIP is a very accepted tool that allows companies to use the Internet connection for establishing telephone call. VoIP can effectively reduce maintenance and operating costs associated with traditional phone lines (Bridge, 2005).

- Virtual Private Networks (VPN). Many franchisors use the Internet to communicate with customers via secure intranet and extranet networks in order to share confidential information and to facilitate the discussion within the franchise system. Tools such as virtual private networks allow 
seamless connectivity between the franchisor and other franchising participants, helping them to reduce costs. VPN enables franchisees to share information securely over the Internet and offers high speed data transfer. In this way, it reduces the cost of connecting remote users, while at the same time increases productivity (ibid).

- Discussion groups and forums. The most popular forms of on-line communication, discussion forums and chat rooms, enable the franchisor to share ideas with franchisees and customers on a daily basis, instead of doing so only on annual conferences and seminars (ibid).

- Blogs. A blog is basically a website or on-line notice board that contains messages so called "post", related to a specific topic. Corporate blogs provide companies the opportunity to communicate with customers in an informal and easily accessible forum. Therefore, franchisor should consider using blogs to communicate with their franchisees and end customers. However, blogs must be updated frequently, at least once a day or in two days, and the franchisor should appoint a person responsible for entering these changes (Rogers and Bennett, 2005).

\section{Comparative Analysis of Using ICT in the Franchise Systems in} Serbia and Croatia and in Developed Countries

Although franchising is a business model, which deserves the attention of both academic and business communities, little attention has been paid to the application of the Internet-based technologies in the franchise sector. For that reason, this paper addresses the issue of using ICT and Internet in franchise systems in developed and underdeveloped countries. The aim of this paper is to analyze the use of ICT and the Internet in franchise systems. Through websites, franchisors provide information and connect with both potential and existing franchisees, as well as with end customers. Internet ensures companies to overcome physical and geographical distance and an opportunity to increase market and service opportunities in the franchise sector. In order to increase competitiveness through the use of Internet based technologies, many franchise organizations are opting for networking. For example, a number of franchises start to use e-commerce, customers and the franchise are connected via an intranet, there is an opportunity to interact with customers and suppliers. The research focuses on two main areas: how franchisors communicate with prospective franchisees and how franchisors communicate with customers. Accordingly, there are two groups of questions which are related to the mentioned fields of our research. Given the fact that we compare the use of ICT and the Internet in developed and underdeveloped countries, the survey included per 10 representative franchise systems from selected countries. On the side of less developed countries, we chose franchise systems from Serbia and Croatia, and on the side of the developed countries we chose representative 
franchise systems from Australia, the USA and the UK, where the development of franchising is on the highest level. We formulated a detailed set of the research questions. Possible answers to these questions are: YES or NO. Answers to these questions are based on the analysis of selected franchising companies' websites in Serbia, Croatia, Australia, the USA and the UK. Questions that have been in the focus of research are as follows:

- Does the website provide information about franchisor's company?

- Does the website provide information that may be of interest for potential franchisees?

- Does the website provide information about services that franchisors provide to franchisees?

- Does the website provide informations about employment opportunities at the franchisor's company?

- Does the website provide franchisees' experiences and recommendations?

- Does the website provide information about fees and costs for potential franchisees?

- Does the website provide conditions that potential franchisees have to fulfill?

- Does the prospective franchisee can send on-line request for additional information about the franchise?

- Does the website provide detailed information about products and services offered by the franchisor's company?

- Can customers order on-line products / services via the franchisor's website?

- Can users pay on-line for ordered products / services via the franchisor's website?

- Does the website provide information about franchisees' locations?

- Does the website provide links to individual web pages or sites that provide detailed information about the franchisees?

- Is there a possibility of connecting franchisors and franchisees through the website?

- Are there any forms of on-line promotion on the company's website (coupons, discounts, gifts)?

- Are there an interactive page for customers on the company's website (eg, chat rooms, games, etc.)?

The survey was conducted from September to the end of December of the year 2013. The aim of this study is to perform a comprehensive on-line analysis of franchising companies' websites, instead of relying on interviewing franchisors about their use of ICT and Internet technologies. This is because franchisors tend to argue that, for example, they enable electronic commerce via their website, but in fact they only provide information about products that can be purchased in franchise units, which is certainly not the same and does not provide objective information. For the purpose of comparative analysis of using 
the ICT and the Internet by the franchising systems in Serbia and worldwide, it was necessary to start from the representative examples of the franchise systems. As examples, we selected ten franchise systems from the USA, UK, Australia, Croatia and Serbia (Table 1 and Table 2).

Table 1 Summary of Representative Examples of Franchise Systems in Serbia and Croatia

\begin{tabular}{|c|c|c|c|c|c|}
\hline \multicolumn{3}{|c|}{ "SERBIA } & \multicolumn{3}{|c|}{ CROATIA } \\
\hline $\begin{array}{l}\text { Franchise } \\
\text { system's } \\
\text { name }\end{array}$ & Core business & $\begin{array}{l}\text { Number of } \\
\text { franchise } \\
\text { units }\end{array}$ & $\begin{array}{l}\text { Franchise } \\
\text { system's } \\
\text { name }\end{array}$ & Core business & $\begin{array}{l}\text { Number of } \\
\text { franchise } \\
\text { units }\end{array}$ \\
\hline $\begin{array}{l}\text { Arcus } \\
\text { Health } \\
\text { Club }\end{array}$ & $\begin{array}{l}\text { Selling massage } \\
\text { chairs }\end{array}$ & 9 & $\begin{array}{l}\text { Body } \\
\text { Creator }\end{array}$ & $\begin{array}{l}\text { Center for } \\
\text { slimming and } \\
\text { reshaping the } \\
\text { female figure }\end{array}$ & 3 \\
\hline $\begin{array}{l}\text { Adore } \\
\text { Chocolat }\end{array}$ & $\begin{array}{l}\text { Producing and } \\
\text { selling sweets }\end{array}$ & 3 & Experience & $\begin{array}{l}\text { Producing and } \\
\text { selling perfumes }\end{array}$ & 2 \\
\hline Rakia bar & $\begin{array}{l}\text { Unique bar } \\
\text { concept }\end{array}$ & 4 & Funny Chips & $\begin{array}{l}\text { Unique fast food } \\
\text { concept }\end{array}$ & 11 \\
\hline Dve smizle & $\begin{array}{l}\text { Selling fashion } \\
\text { jewelry }\end{array}$ & 39 & Surfer & $\begin{array}{l}\text { Fast food } \\
\text { restaurant }\end{array}$ & 3 \\
\hline $\begin{array}{l}\text { Battery } \\
\text { Centar }\end{array}$ & $\begin{array}{l}\text { Servicing and } \\
\text { selling batteries } \\
\text { and } \\
\text { accumulators }\end{array}$ & 3 & $\begin{array}{l}\text { Centar } \\
\text { energije }\end{array}$ & $\begin{array}{l}\text { Implementation of } \\
\text { energy efficiency } \\
\text { through use of } \\
\text { renewable energy }\end{array}$ & 14 \\
\hline MEGA & $\begin{array}{l}\text { Metal } \\
\text { processing and } \\
\text { manufacturing } \\
\text { decorative items }\end{array}$ & 21 & $\begin{array}{l}\text { Centar } \\
\text { Mihaela }\end{array}$ & $\begin{array}{l}\text { Center of Chinese } \\
\text { Medicine }\end{array}$ & 1 \\
\hline $\begin{array}{l}\text { AMC } \\
\text { Afrodita }\end{array}$ & $\begin{array}{l}\text { Design and } \\
\text { production of } \\
\text { clothing }\end{array}$ & 12 & Rubelj Grill & Restaurant & 11 \\
\hline Doming & $\begin{array}{l}\text { Selling } \\
\text { installation } \\
\text { equipment for } \\
\text { heating, } \\
\text { plumbing, } \\
\text { ventilation etc. }\end{array}$ & 12 & $\begin{array}{l}\text { Skandal } \\
\text { fashion }\end{array}$ & $\begin{array}{l}\text { Creating and } \\
\text { producing unique } \\
\text { fashion products }\end{array}$ & 3 \\
\hline Kontiki & Travel agency & 4 & $\begin{array}{l}\text { San } \\
\text { Francisco } \\
\text { Coffee } \\
\text { House }\end{array}$ & Coffee Shop & 2 \\
\hline Fl Fly travel & Travel agency & 11 & Lens optika & Optical store & 2 \\
\hline
\end{tabular}

Source: Official websites of selected companies

Note: Authors selected franchising companies as representative examples from selected countries 
Table 2 Summary of Representative Examples of the Franchise Systems in Australia, the U.S. and UK

\begin{tabular}{|c|c|c|c|c|c|c|c|c|}
\hline \multicolumn{3}{|c|}{ AUSTRALIA } & \multicolumn{3}{|c|}{ USA } & \multicolumn{3}{|c|}{ UK } \\
\hline $\begin{array}{l}\text { Franchise } \\
\text { system's } \\
\text { name }\end{array}$ & $\begin{array}{l}\text { Core } \\
\text { business }\end{array}$ & $\begin{array}{l}\text { Number } \\
\text { of } \\
\text { franchis } \\
\text { e units }\end{array}$ & $\begin{array}{l}\text { Franchise } \\
\text { system's } \\
\text { name }\end{array}$ & $\begin{array}{l}\text { Core } \\
\text { business }\end{array}$ & $\begin{array}{l}\text { Number } \\
\text { of } \\
\text { franchise } \\
\text { units }\end{array}$ & $\begin{array}{l}\text { Franchise } \\
\text { system's } \\
\text { name }\end{array}$ & $\begin{array}{l}\text { Core } \\
\text { business }\end{array}$ & $\begin{array}{l}\text { Number } \\
\text { of } \\
\text { franchise } \\
\text { units }\end{array}$ \\
\hline $\begin{array}{l}\text { Bakers } \\
\text { Delight }\end{array}$ & Bakery & 700 & $\begin{array}{l}\text { All } \\
\text { Battery } \\
\text { Center }\end{array}$ & $\begin{array}{l}\text { Selling } \\
\text { of } \\
\text { batteries }\end{array}$ & 202 & $\begin{array}{l}\text { Costa } \\
\text { Coffee }\end{array}$ & $\begin{array}{l}\text { Coffee } \\
\text { shop }\end{array}$ & 1900 \\
\hline $\begin{array}{l}\text { Donut } \\
\text { King }\end{array}$ & $\begin{array}{l}\text { Bakery } \\
\text { and } \\
\text { coffee } \\
\text { shop }\end{array}$ & 320 & $\begin{array}{l}\text { Fit Body } \\
\text { Boot } \\
\text { Camp }\end{array}$ & $\begin{array}{l}\text { Fitness } \\
\text { center } \\
\text { and gym }\end{array}$ & 44 & $\begin{array}{l}\text { Rosemary } \\
\text { Conley }\end{array}$ & $\begin{array}{l}\text { Club for } \\
\text { fitness } \\
\text { and diet }\end{array}$ & 170 \\
\hline $\begin{array}{l}\text { Healthy } \\
\text { Habits }\end{array}$ & $\begin{array}{l}\text { Healthy } \\
\text { food } \\
\text { producti } \\
\text { on }\end{array}$ & 28 & $\begin{array}{l}\text { Forever } \\
\text { Yogurt }\end{array}$ & $\begin{array}{l}\text { Producing } \\
\text { and selling } \\
\text { yogurt }\end{array}$ & 34 & Chemex & $\begin{array}{l}\text { Selling } \\
\text { hygienic } \\
\text { products }\end{array}$ & 200 \\
\hline Oporto & $\begin{array}{l}\text { Restaur } \\
\text { ant }\end{array}$ & 140 & $\begin{array}{l}\text { Office } 1 \\
\text { Superstore }\end{array}$ & $\begin{array}{l}\text { Selling } \\
\text { office } \\
\text { material } \\
\text { and } \\
\text { furniture }\end{array}$ & 500 & Domino's & $\begin{array}{l}\text { Fast food } \\
\text { restaurant }\end{array}$ & 9350 \\
\hline $\begin{array}{l}\text { Fernwood } \\
\text { Fitness }\end{array}$ & $\begin{array}{l}\text { Fitness } \\
\text { center } \\
\text { and gym }\end{array}$ & 70 & McDonald's & $\begin{array}{l}\text { Fast food } \\
\text { restaurant }\end{array}$ & 27074 & $\begin{array}{l}\text { Body } \\
\text { Shop }\end{array}$ & $\begin{array}{l}\text { Selling } \\
\text { natural } \\
\text { products } \\
\text { for skin } \\
\text { and } \\
\text { beauty }\end{array}$ & 1500 \\
\hline $\begin{array}{l}\text { Step } \\
\text { into life }\end{array}$ & $\begin{array}{l}\text { Fitness } \\
\text { center } \\
\text { and gym }\end{array}$ & 164 & $\begin{array}{l}\text { Dunkin' } \\
\text { Donuts }\end{array}$ & $\begin{array}{l}\text { Bakery } \\
\text { and } \\
\text { coffee } \\
\text { shop }\end{array}$ & 10700 & Clarks & $\begin{array}{l}\text { Selling } \\
\text { footwear }\end{array}$ & 550 \\
\hline $\begin{array}{l}\text { Cartridge } \\
\text { World }\end{array}$ & $\begin{array}{l}\text { Selling } \\
\text { toner } \\
\text { cartridges }\end{array}$ & 154 & KFC & $\begin{array}{l}\text { Fast food } \\
\text { restaurant }\end{array}$ & 4199 & $\begin{array}{l}\text { Candy } \\
\text { Creations }\end{array}$ & $\begin{array}{l}\text { Producing } \\
\text { and selling } \\
\text { sweets }\end{array}$ & 30 \\
\hline Cafe $2 u$ & $\begin{array}{l}\text { Mobile } \\
\text { coffee } \\
\text { industry }\end{array}$ & 200 & $\begin{array}{l}\text { Anytime } \\
\text { Fitness }\end{array}$ & $\begin{array}{l}\text { Fitness } \\
\text { center } \\
\text { and gym }\end{array}$ & 2100 & $\begin{array}{l}\text { Global } \\
\text { travel } \\
\text { group }\end{array}$ & $\begin{array}{l}\text { Travel } \\
\text { agency }\end{array}$ & 500 \\
\hline Optus & $\begin{array}{l}\text { Provider } \\
\text { of ICT } \\
\text { services }\end{array}$ & 295 & $\begin{array}{l}\text { Cruise } \\
\text { Holidays }\end{array}$ & $\begin{array}{l}\text { Travel } \\
\text { agency }\end{array}$ & 116 & $\begin{array}{l}\text { Shake } \\
\text { away }\end{array}$ & $\begin{array}{l}\text { Milkshake } \\
\text { bar }\end{array}$ & 200 \\
\hline $\begin{array}{l}\text { Mad } \\
\text { Mex }\end{array}$ & Restaurant & 37 & $\begin{array}{l}\text { Burger } \\
\text { King }\end{array}$ & $\begin{array}{l}\text { Fast food } \\
\text { restaurant }\end{array}$ & 10144 & $\begin{array}{l}\text { Perfect } \\
\text { pizza }\end{array}$ & $\begin{array}{l}\text { Fast food } \\
\text { restaurant }\end{array}$ & 55 \\
\hline
\end{tabular}

Source: Official websites of selected companies

Note: Authors selected franchising companies as representative examples from selected countries 
Based on analysis of the companies' websites in selected countries, we compiled the answers to the above questions (YES or NO). Answers to the questions are coded so that, if the answer to the question is YES, it is marked with 1 , and if the answer is NO, it is marked with 0 . Results are summarized by countries in tables 3 and 4 . Table 3 shows the use of franchisors' websites for connecting with existing and potential franchisees. Table 4 shows the use of franchisors' websites for establishing a relationship with end customers. Comprehensive analysis of the obtained data shows that, generally speaking, the use of IT and the Internet in the development of franchise systems in Serbia and Croatia in almost all aspects of their use lags behind the developed market economies (USA, Australia, and UK).

Analysis of data about using franchisors' websites for connecting with existing and potential franchisees shows that companies' websites from Serbia and Croatia are mainly for information purposes. Specifically, almost all companies in Serbia and Croatia have on their websites information about the franchisor (100\% of the companies), information that are relevant for potential franchisees (80\% and $70 \%$ of the surveyed companies, retrospectively), and information about services provided by the franchisor $(80 \%$ or $100 \%$ of companies surveyed, retrospectively). Only one company from Serbia (Fly Fly Travel) provides insight into the experiences of existing franchisees on its web site in addition to information that may be of importance for potential franchisees. In Croatia, none of the analyzed companies does not set the experience of its existing franchisees on web site. On the other hand, $90 \%$ of companies in Australia, 70\% of companies in the USA and 50\% of the analyzed franchise companies in the UK has set the experience of existing franchisees on their web sites, in order to attract and help potential franchisees to decide to enter into a franchise system.

When it comes to information about fees and costs for potential franchisees, the most of franchisors from analyzed developed market economies have these informations on their web sites, but these information lack on web sites of the most companies from Serbia and Croatia. Nearly all analyzed franchise systems from the USA, Australia and the UK have on their web site information about conditions that franchisees must fulfill in order to become the part of the franchising system. On the other hand, the percentage of companies in Serbia and Croatia which believes that this information is of importance, is much smaller. Four out of ten of the analyzed companies from Serbia and Croatia provide an opportunity for potential franchisees to send on-line request for additional information to the franchisor, while all analyzed companies in the U.S., Australia and the UK offer this option. In this manner, it is much easier for future franchisees to establish communication and acquire additional information about franchise system. Companies in Serbia and Croatia do not offer links to individual franchisees' web pages. In Australia, the percentage of 
companies which have links to the franchisee's pages on their web sites is $10 \%$, in the United Kingdom it is $20 \%$, while in the USA it is $60 \%$. Of particular importance is the issue related to the ability to connect franchisees with the franchisor through the web site. Only three companies out of ten from Serbia and only one out of ten analyzed companies from Croatia offer this service. On the other hand, companies from developed countries emphasize the necessity of increasing interaction and on-line communication between members of the franchise system. Thus, $60 \%$ of analyzed companies from Australia, 50\% of analyzed companies from the UK and $90 \%$ of analyzed companies from the United States provide the ability to connect franchisee with the franchisor through website. Based on the foregoing, it can be concluded that the use of Internet technology for establishing relationships between franchisees and franchisors is more presented in developed countries compared to Serbia and Croatia, which is consistent with the initial assumptions of this study.

Table 3 The Use of Franchisors' Websites for Connecting with Existing and Potential franchisees

\begin{tabular}{|l|l|l|l|l|l|}
\hline & Serbia & Croatia & Australia & USA & UK \\
\hline Information about franchisors & $100 \%$ & $100 \%$ & $100 \%$ & $100 \%$ & $100 \%$ \\
\hline $\begin{array}{l}\text { Information important for } \\
\text { potential franchisees }\end{array}$ & $80 \%$ & $70 \%$ & $100 \%$ & $100 \%$ & $100 \%$ \\
\hline $\begin{array}{l}\text { Informations about services } \\
\text { provided by the franchisor }\end{array}$ & $80 \%$ & $100 \%$ & $100 \%$ & $100 \%$ & $100 \%$ \\
\hline $\begin{array}{l}\text { Franchisees' experiences and } \\
\text { recommendations }\end{array}$ & $10 \%$ & $0 \%$ & $90 \%$ & $70 \%$ & $50 \%$ \\
\hline $\begin{array}{l}\text { Information about fees and } \\
\text { costs for potential franchisees }\end{array}$ & $40 \%$ & $20 \%$ & $90 \%$ & $100 \%$ & $60 \%$ \\
\hline $\begin{array}{l}\text { Conditions that are necessary } \\
\text { to fulfill by the potential } \\
\text { franchisees }\end{array}$ & $50 \%$ & $30 \%$ & $100 \%$ & $100 \%$ & $90 \%$ \\
\hline $\begin{array}{l}\text { Possibility of franchisee to } \\
\text { send on-line request for } \\
\text { additional information }\end{array}$ & $40 \%$ & $40 \%$ & $100 \%$ & $100 \%$ & $100 \%$ \\
\hline $\begin{array}{l}\text { Links to individual web pages } \\
\text { or websites that provide } \\
\text { detailed information about } \\
\text { franchisees }\end{array}$ & $0 \%$ & $0 \%$ & $10 \%$ & $60 \%$ & $20 \%$ \\
\hline $\begin{array}{l}\text { Connection between } \\
\text { franchisees and franchisor via }\end{array}$ & $30 \%$ & $10 \%$ & $60 \%$ & $90 \%$ & $50 \%$ \\
\hline
\end{tabular}

Source: Our own calculations based on analysis of franchising companies' websites in the selected countries 
In addition to establishing relationships with potential and existing customers, franchisors communicate with end customers through their website. All of analyzed franchise companies in selected countries post informations about products and services on their websites. Also, almost all franchisors indicate franchisees' location to end customers through their websites, so that end customers can easily find a franchise unit in the neighborhood. Half of analyzed companies in Serbia provide information about employment opportunities at the franchisor's company on their website, while only two out of ten of analyzed companies in Croatia provide this information. The most of companies in the developed market economies enable individuals to be informed about employment opportunities through the franchisor's website (90\% of the companies in Australia and the United States, and $80 \%$ of the companies in the UK). Various on-line forms of promotions, such as coupons, discounts and gifts are available at most of franchise companies' websites in all analyzed countries. However, franchisors from Serbia and Croatia do not set interactive content for customers on their websites.

A relatively small percentage of franchise companies in all analyzed countries perform e-commerce via their website. This is because they believe that ecommerce via franchisor's website may directly jeopardize the sale in franchise units. So, in order to avoid conflicts of interest, more than a half of the companies decide only to provide detailed information about products and services and franchisees' locations through the website, and to direct customers to purchase products in the nearest franchise unit. Only $40 \%$ of the companies from Serbia and $30 \%$ of the companies in Croatia offer the possibility of on-line ordering of products/services via franchisor's website. Percentage of analyzed companies that offer the possibility of on-line payment for ordered products and services through websites is even lower (30\% of analyzed companies from Serbia and only $10 \%$ of analyzed companies from Croatia). On the other hand, only three out of ten analyzed companies from Australia, and five out of ten analyzed companies from the UK allow customers to order and pay for ordered products and services online. As for the USA, $50 \%$ of analyzed companies have an option of on-line ordering, and $40 \%$ of analyzed companies have an option of on-line payments for products and services ordered through franchisor's website. Therefore, the use of Internet technology for establishing a relationship with end customers is more presented in franchise systems in developed countries than in Serbia and Croatia. Based on the overall analysis of the use of franchisor's websites, in order to establish relationships with existing and potential franchisees, as well as the end customers, it can be concluded that the use of Internet technology in Serbia and Croatia by franchisors is more focused on providing information to future franchisees and end customers than on providing services and connectivity. Therefore, it is necessary to improve franchise companies' websites in Serbia and Croatia, in order to establish better communication and interaction with actors that are important for the success of the entire franchise concept. 
Table 4 The Use of Franchisors' Websites for Establishing a Relationship with end customers

\begin{tabular}{|l|l|l|l|l|l||}
\hline & Serbia & Croatia & Australia & USA & UK \\
\hline $\begin{array}{l}\text { Information about } \\
\text { employment opportunities at } \\
\text { the franchisor's company }\end{array}$ & $\mathbf{5 0 \%}$ & $\mathbf{2 0 \%}$ & $\mathbf{9 0 \%}$ & $\mathbf{9 0 \%}$ & $\mathbf{8 0 \%}$ \\
\hline $\begin{array}{l}\text { Informationsabout products } \\
\text { and services offered by the } \\
\text { franchisor }\end{array}$ & $\mathbf{1 0 0 \%}$ & $\mathbf{1 0 0 \%}$ & $\mathbf{1 0 0 \%}$ & $\mathbf{1 0 0 \%}$ & $\mathbf{1 0 0 \%}$ \\
\hline $\begin{array}{l}\text { On-line ordering of products } \\
\text { I services via the franchisor's } \\
\text { website }\end{array}$ & $\mathbf{4 0 \%}$ & $\mathbf{3 0 \%}$ & $\mathbf{3 0 \%}$ & $\mathbf{5 0 \%}$ & $\mathbf{5 0 \%}$ \\
\hline $\begin{array}{l}\text { On-line payment for ordered } \\
\text { products / services via the } \\
\text { franchisor's website }\end{array}$ & $\mathbf{3 0 \%}$ & $\mathbf{1 0 \%}$ & $\mathbf{3 0 \%}$ & $\mathbf{4 0 \%}$ & $\mathbf{5 0 \%}$ \\
\hline $\begin{array}{l}\text { Information about } \\
\text { franchisees' locations }\end{array}$ & $\mathbf{1 0 0 \%}$ & $\mathbf{1 0 0 \%}$ & $\mathbf{1 0 0 \%}$ & $\mathbf{1 0 0 \%}$ & $\mathbf{8 0 \%}$ \\
\hline $\begin{array}{l}\text { On-line forms of promotion } \\
\text { on the franchisor's website } \\
\text { coupons, discounts, gifts) }\end{array}$ & $\mathbf{7 0 \%}$ & $\mathbf{5 0 \%}$ & $\mathbf{7 0 \%}$ & $\mathbf{7 0 \%}$ & $\mathbf{8 0 \%}$ \\
\hline $\begin{array}{l}\text { Interactive pages for } \\
\text { customers on franchisor's } \\
\text { website (chat rooms, games) }\end{array}$ & $\mathbf{0 \%}$ & $\mathbf{0 \%}$ & $\mathbf{5 0 \%}$ & $\mathbf{4 0 \%}$ & $\mathbf{3 0 \%}$ \\
\hline
\end{tabular}

Source: Our own calculations based on the analysis of the company's website in selected countries

\section{Methodology, Results and Discussion of Research Results}

A large number of world famous franchise systems use their website, among other things, for connecting participants in order to provide faster exchange of relevant information and improving communication between franchisors and franchisees. In fact, the web presence allows franchise companies to improve interaction within the franchise system through internet technology such as intranet and extranet. Intranet uses web architecture on private corporate networks or on password-protected public networks. Extranet also uses web architecture on private or password-protected public network, but may include support for dial-up access, both for internal staff, as well as close partners. Intranet and extranet are attractive for both franchisors and franchisees, because they do not require great expenses. Franchisees will be required to invest only in computer (which they already may have for other business requirements) and to pay monthly Internet access. In this way, franchisor can provide better communication with franchisees and improve control of each franchise unit (Dickey and Ives, 2000). In this sense, intranet and extranet can become a 
"lifeblood" of the franchise systems (Kennedy, 2006). There are many benefits of using intranet and extranet, including communication with franchisees, collecting financial information from franchisees, submitting monthly reports, providing on-line training and support, etc. It may be required from franchisees to pay reasonable compensation for the creation, maintenance and support of network for participants connecting in the franchise system (Rogers and Bennett, 2005).

Table 5 Proportion of Franchise Units that Use the Website for Connecting Franchisors and Franchisees by Countries

\begin{tabular}{|l|l|l|l||}
\hline Country & $\begin{array}{l}\text { The total } \\
\text { number of } \\
\text { franchise } \\
\text { units in all } \\
\text { analyzed } \\
\text { companies in } \\
\text { country }\end{array}$ & $\begin{array}{l}\text { The number of } \\
\text { franchising units that } \\
\text { allow connection between } \\
\text { franchisors and } \\
\text { franchisees through the } \\
\text { website }\end{array}$ & $\begin{array}{l}\text { The percentage of } \\
\text { franchising units, which } \\
\text { enable connecting } \\
\text { franchisors and } \\
\text { franchisees through the } \\
\text { website }\end{array}$ \\
\hline Serbia & 118 & 36 & $30,51 \%$ \\
\hline Croatia & 52 & 14 & $26,92 \%$ \\
\hline Australia & 2108 & 850 & $40,37 \%$ \\
\hline USA & 55113 & 55070 & $99,92 \%$ \\
\hline UK & 14455 & 11770 & $81,42 \%$ \\
\hline
\end{tabular}

Source: Authors' own calculations

Having in mind that the use of modern ICT and the Internet has positive effects on the development of franchising, we analyzed whether there is a connection between the franchisors and franchisees via website, and the number of given franchises. According to official data from companies' websites (and by direct contact by phone and mail for franchise companies in Serbia), we determined the number of franchise units of each company in selected countries. Then we found the total number of franchise units of all of the companies in different countries. Based on the above analysis, we determined which of the analyzed companies provide the possibility of on-line linking the participants in franchise systems via website. We counted the number of franchise units and the percentage of the total number of franchise units that allow franchisors and franchisees to connect through the website. In this manner, we get two variables: the percentage use of website for connecting franchisors and franchisees, as independent variable, and the number of franchise units, as the dependent variable. Based on the data, we see that a relatively small number of franchise units in Serbia and Croatia has the option of on-line linking: $30.51 \%$ and $26.92 \%$ of the observed franchised units, respectively. In Australia, there is still a relatively small number of franchise 
units among which exists a on-line linking, only $40.37 \%$ of the analyzed franchise units. In the UK, even $81.42 \%$ of franchise units of surveyed companies have the ability to connect via franchisor's website. The use of franchisor's website for connecting with franchisees is most common in the USA, where $99.92 \%$ of franchise units are interconnected on-line (Table 5).

We started from the hypothesis that the increase of using the website for connecting franchisors and franchisees cause increase in the number of given franchises, and that there is a positive correlation between these variables. As already mentioned, the observed variables are: the percentage use of website for connecting franchisors and franchisees, as the independent variable, and the number of franchise units in analyzed countries, as the dependent variable. We used SPSS statistical software for analysis, and results are shown in Table 6.

Table 6 Correlation Analysis

\begin{tabular}{|c|c|c|c|}
\hline & & $\begin{array}{l}\text { The percentage of } \\
\text { franchising units, } \\
\text { which enable } \\
\text { connecting } \\
\text { franchisors and } \\
\text { franchisees through } \\
\text { the website }\end{array}$ & $\begin{array}{l}\text { The number of } \\
\text { franchising } \\
\text { units }\end{array}$ \\
\hline $\begin{array}{l}\text { The percentage } \\
\text { of franchising } \\
\text { units, which } \\
\text { enable } \\
\text { connecting } \\
\text { franchisors } \\
\text { and franchisees } \\
\text { through the } \\
\text { website }\end{array}$ & $\begin{array}{l}\text { Pearson's } \\
\text { correlation } \\
\text { coefficient } \\
\text { Significance (two- } \\
\text { tailed) } \\
\text { N }\end{array}$ & 1 & $\begin{array}{r}0,893^{*} \\
0,041\end{array}$ \\
\hline $\begin{array}{l}\text { The number of } \\
\text { franchising } \\
\text { units }\end{array}$ & $\begin{array}{l}\text { Pearson's } \\
\text { correlation } \\
\text { coefficient } \\
\text { Significance (two- } \\
\text { tailed) } \\
\text { N }\end{array}$ & $\begin{array}{r}0,893 * \\
0,041\end{array}$ & 5 \\
\hline
\end{tabular}

* Correlation is significant at the 0.05 level (two-tailed)

Source: Authors' own calculations using the SPSS 
Results of correlation analysis showed that the correlation coefficient is: $r=$ $0.893, r \geq 0.7$, and it can be concluded that there is a strong positive correlation between the use of the website for connecting the franchisor and franchisees and the number of franchise units. If we compare value $t=3.437$, with the value in T-table, that indicates that $\mathrm{p} \leq 0.05$. Correlation is significant on 0.05 level $(p \leq 0.05)$. Therefore, we can conclude that there is a statistically significant strong positive correlation between the use of the website for connecting franchisors and franchisees and the number of franchise units. This means that the increase in the use of the website for connecting participants in a franchise system will increase the number of franchise units in franchise concept. It can be concluded that less use of modern technology and the Internet in developing countries, such as Serbia and Croatia, affects the slower development of franchising and slower expansion of the network of franchised units than in developed countries where the use of ICT and the Internet is at a much higher level, which prove starting assumption of the study.

\section{Conclusions}

Franchising systems increasingly gain importance in our country and worldwide. The use of modern technology and the Internet is of crucial significance for the further course of development of franchise concepts. Using Internet based technology for connecting participants in franchising systems aim to increase the efficiency within the entire system. The paper points out the importance of using websites for establishing relationships with both existing and potential franchisees, as well as the end customers. Based on a comparative analysis of using the ICT in selected franchise systems in five countries: Serbia, Croatia, Australia, United States and United Kingdom, we reach relevant conclusions. Generally, the use of modern technology and the Internet is much lower in the franchise systems in Serbia and Croatia than in developed market economies. Specifically, websites of franchise companies in Serbia and Croatia are more focused on providing information to prospective franchisees and end customers than to provide services and connectivity. On the other hand, ICT and the Internet are being more used to establish a relationship with end customers in developed market economies than in Serbia and Croatia. Correlation analysis showed a statistically significant strong positive correlation between using the website to connect franchisor and franchisees and the number of franchise units. Therefore, the paper proves that the increase of using the website for connecting the participants in a franchise system increases the number of franchise units in system.

While most franchisors, in our country and abroad, have a number of benefits from using the ICT and the Internet, there are still a lot of areas that can be exploited more efficiently. Further research should be focused on developing franchisor's on-line strategies and identifying ways in which these strategies can 
affect their relationship with franchisees and end customers. Facebook, Twitter and LinkedIn are becoming important marketing tools for companies on a national and international level. Further research may be focused on intensity of using Facebook, Twitter and LinkedIn by franchisors to promote the franchise concept, as well as the possibility of developing franchisor's own applications. One of the issues to be addressed in the future is the use of a Webinar in order to better communicate within the franchise system and with end customers. Further researches can be focused on the intensity of using blogs and VoIP by the franchisor. One of the biggest challenges for the franchisor is harmonization with financial reporting requirements. In recent years, on-line accounting applications have provided a solution to this problem, and the future research could be devoted to the analysis of using these applications in Serbia and globally. These Internet-based applications provide the franchisor' access to franchisee's accounting data in real time. Based on these applications, franchisor receives all relevant information for his business, but he can also use them to direct franchisees how to better focus on the financial management in their franchise business.

This study provides an overview and analysis of the actual state of usage the ICT and the Internet in selected franchise systems, based on analysis of their websites, instead of relying on interviewing franchisors about how franchise systems operate on-line. The main limitation of this study is that research of franchisor's websites provides a snapshot of the situation at the moment (for a given time frame). Websites change on a daily basis, and accordingly, information on web sites are continually updated. Given the fact that franchising is a very popular business model, new franchises are created and a large number of franchise units arise every day. At the same time, a number of franchise units cease to operate, so the data on the number of franchise units are subject to constant change, which is still one of the limitation of this study..

\section{References}

Alpeza, M. and A. Erceg (2012) Franšiza - 20 najtraženijih odgovora, Centar za poduzetništvo Osijek, Ministarstvo poduzetništva i obrta, Osijek, str. 4-6

Biland, A.T. (2000) „A question of value - e-commerce works best as an enabler of the personal relationship between businesses and their customers", Information Week, 6: 214

Boyle, B.A. and L.F. Alwitt (1999) „Internet use within the US plastics industry“, Industrial Marketing Management, 28 (4): 327-341.

Bridge, G. (2005) „Embracing Technology: Building a Stronger System with Effective Franchisee Relations", Franchising World, http://www.franchise.org/FranchiseNews-Detail.aspx?id=40574 (pristupljeno: 18.12 .2013 .)

British Franchise Association (2013) NatWest/bfa Franchise Survey, www.thebfa.org (pristupljeno: 05.06.2013.) 
Centar za franšizing, Privredna komora Srbije (2013) Franšizing - najčešće postavljana pitanja, http://www.pks.rs/SADRZAJ/Files/Frans\%20brosura.pdf (pristupljeno: 08.04.2013.)

Ćuzović, S. (2010) "Franšizing kao standardizovan model internacionalnog biznisa", Ekonomika preduzeća, 7-8: 339-347.

Dickey, M. and B. Ives (2000) „The Impact of Intranet Technology on Power in Franchisee/ Franchisor Relationships“, Information Systems Frontiers, 2 (1): 99-114.

Dixon, H. and B. Quinn (2004) „Franchising and the Internet: an exploratory study of franchisor Web sites“, Internet Research, 14 (4): 311-322.

Duckett, B. (2008) "Business format franchising: a strategic option for business growth - at home and abroad", Strategic Direction, 24 (2): 3-4.

Dutta, S. and B. Biren (2001) „Business Transformation on the Internet: Results from the 2000 Study“, European Management Journal, 19 (5): 449-62.

Enders, A. And T. Jelassi (2000) "The converging business models of Internet and bricksand-mortar retailers", European Management Journal, 18 (5): 542-550.

Fisher, L. and C.L. Mullin (2000) "To 'e' or not to 'e'? using electronic communication in franchise sales", Franchising World, 32 (1): 30-33.

Floriani, B. and M.K. Lindsey (2001) "The continuing impact of the Internet on international franchising", International Journal of Franchising and Distribution Law, 3 (3): 175-237.

Franklin, M. (2005) „Introducing the Virtual Brochure: Online Technology That Turns Franchise Leads Into Franchisees“, Franchising World, http://www.franchise.org/Franchise-News-Detail.aspx?id=40604 (pristupljeno: 18.12.2013.)

Franson, B., and D. DeSmith (2005) „Does the Internet Solve Franchisees' Problems?“, Franchising World, http://www.franchise.org/Franchise-News-Detail.aspx?id= 40616 (pristupljeno: 18.12.2013.)

Frazer, L., S. Weaven, J. Giddings, and D. Grace (2012) "What went wrong? Franchisors and franchisees disclose the causes of conflict in franchising", Qualitative Market Research: An International Journal, 15 (1): 87 - 103.

Gilbert, A. (2001) „The B-To-B Integration Equation“, Information Week, 12: 41.

Gotsopoulou, N. (2000) "Legal issues on international franchising and electronic commerce", Business Law Review, 21 (12): 288-290.

Griffith, D.A. and J.W. Palmer, (1999) „Leveraging the Web for corporate success“, Business Horizons, 42 (1): 3-11.

Kennedy, T. (2006) „Information Technology in Franchising“, Franchising World, http://www.franchise.org/Franchise-News-Detail.aspx?id=40564 (pristupljeno: 22.12.2013.)

Kothandaraman, P. and D.T. Wilson (2001) „The future of competition: value creating networks“, Industrial Marketing Management, 30 (4): 379-389.

Lancioni, R., H. J. Schau, and M.F. Smith (2003) „Internet impacts on supply chain management", Industrial Marketing Management, 32(3): 173-175.

Love, T. (1998) „High tech meets franchising“, National Business, 86 (6): 77-82. 
Martin, D. (1999) „Real world Internet applications that franchise companies actually use“, Franchise World, 31 (4): 22-26.

Merrilees, B. and L. Frazer (2006) "Entrepreneurial franchisees have hidden superior marketing systems", Qualitative Market Research: An International Journal, 9 (1): $73-85$.

MSA Worldwide (2011) Franchising and the Internet, http://www.msaworldwide.com/franchising-resources/articles/franchising_and_ the_internet_-_part_1(pristupljeno: 22.12.2013.)

Nijmeijer, K., I. N. Fabbricotti, and R. Huijsman, (2014) "Making Franchising Work: A Framework Based on a Systematic Review", International Journal of Management Reviews, 16 (1): 62-83.

O’Brien, K. (2008) „Grow Your Franchise with Online Marketing Tools“, Franchising World, http://www.franchise.org/Franchise-News-Detail.aspx?id=41890 (pristupljeno: 18.12.2013.)

Perrigot, R. and T. Pénard (2012) „Determinants of E-commerce adoption by franchisors: Insights from the U.S. market“", 26th Annual Conference of the International Society of Franchising (ISoF), Fort Lauderdale, USA, May.

Plave, L.J. and R.B. Amolsch (2000) "How to implement dot.com franchising solutions: two aspects of a multifaceted issue", Franchising World, 32, (5): 17-19.

Rao, S. and L. Frazer (2005) „The use of Internet-based Technologies in Australian Franchise Systems: A Preliminary Study“, Journal of Internet Business, 2: 1-19.

Rogers, J. and C. Bennett (2005) „Effective Use of the Internet“, Franchising World, http://www.franchise.org/Franchise-News-Detail.aspx?id=40562 (pristupljeno: 22.12.2013.)

Rogers, J., C. Bennett and S. Grewal (2007) „E-Commerce for Successful Franchisors“, Franchising World, http://www.franchise.org/Franchise-News-Detail.aspx?id $=35526$ (pristupljeno: 18.12 .2013 .)

Spindel, B. (2008) "No-Brainer" Technologies, Franchising World, http://www.franchise.org/Franchise-News-Detail.aspx?id=41894 (pristrupljeno: 18.12.2013.)

Stefanović, S. i M. Stanković, (2013) “Komparativna analiza razvoja franšizinga u Srbiji i svetu“ Marketing, 44 (2): 115-127.

Trice, M.B. (2001) "Managing Internet issues within the franchise system: a legal perspective", Franchising World, 33 (5): 37-8.

Vilchis, D. (2001) „Intranet/Extranet systems user in a new way of life for franchise companies", Franchise World, 44 (4): 19-22.

Watson, A., D.A. Kirby and J. Egan (2002) "Franchising, retailing and the development of e-commerce", International Journal of Retail \& Distribution Management, 30 (5): 228-237.

Zettelmeyer, F. (2000) „Expanding to the Internet: Pricing and communications strategies when firms compete on multiple channels", Journal of Marketing Research, 37 (3): 292-309.

www.batterycentar.rs (pristupljeno: 10.12.2013.)

www.coca-colahellenic.rs (pristupljeno: 10.12.2013.)

www.cokolada.co.rs (pristupljeno: 10.12.2013.)

www.costacoffee.com (pristupljeno: 12.12.2013.) 
www.dvesmizle.rs (pristupljeno: 10.12.2013.)

www.dunkindonuts.com (pristupljeno: 14.12.2013.)

www.mcdonalds.com (pristupljeno: 12.12.2013.)

www.office1.rs (pristupljeno: 14.12.2013.)

www.rakiabar.com (pristupljeno: 12.12.2013.)

www.centar-energije.com (pristupljeno: 14.12.2013.)

www.surfer.com.hr (pristupljeno: 14.12.2013.)

www.experience.com.hr (pristupljeno: 14.12.2013.)

www.funnychips.net (pristupljeno: 14.12.2013.)

www.mihaela.hr (pristupljeno: 14.12.2013.)

www.rubelj-grill.hr (pristupljeno: 14.12.2013.)

www.skandal.hr (pristupljeno: 14.12.2013.)

www.sfch.hr (pristupljeno: 14.12.2013.)

www.lens-optika.hr (pristupljeno: 14.12.2013.)

www.bodycreator.com (pristupljeno: 14.12.2013.)

www.bakersdelight.com.au (pristupljeno: 24.12.2013.)

www.donutking.com (pristupljeno: 24.12.2013.)

www.healthyhabits.com.au (pristupljeno: 24.12.2013.)

www.oporto.com.au (pristupljeno: 24.12.2013.)

www.fernwoodfitness.com.au (pristupljeno: 24.12.2013.)

www.stepintolife.com.au (pristupljeno: 24.12.2013.)

www.cartridgeworld.co.au (pristupljeno: 24.12.2013.)

www.cafe2u.com (pristupljeno: 24.12.2013.)

www.optus.com.au (pristupljeno: 24.12.2013.)

www.madmex.com.au (pristupljeno: 24.12.2013.)

www.allbatteryfranchise.com (pristupljeno: 12.12.2013.)

www.myfitbodybootcamp.com (pristupljeno: 12.12.2013.)

www.foreveryogurt.com (pristupljeno: 12.12.2013.)

www.kfc.com (pristupljeno: 12.12.2013.)

www.anytimefitness.com (pristupljeno: 12.12.2013.)

www.cruiseholidays.com (pristupljeno: 12.12.2013.)

www.bk.com (pristupljeno: 12.12.2013.)

www.thebodyshop.com (pristupljeno: 14.12.2013.)

www.clarks.com (pristupljeno: 14.12.2013.)

www.candycreationsuk.co.uk (pristupljeno: 14.12.2013.)

www.globaltravelgroup.com (pristupljeno: 14.12.2013.)

www.shakeaway.com (pristupljeno: 14.12.2013.)

www.perfectpizza.co.uk (pristupljeno: 14.12.2013.)

www.arcushealth.com (pristupljeno: 14.12.2013.)

www.megaline.rs (pristupljeno: 14.12.2013.)

www.amcafrodita.rs (pristupljeno: 14.12.2013.)

www.doming.rs (pristupljeno: 24.12.2013.)

www.kontiki.rs (pristupljeno: 10.12.2013.)

www.flyflytravel.com (pristupljeno: 10.12.2013.) 


\section{ULOGA INFORMACIONO-KOMUNIKACIONIH TEHNOLOGIJA I INTERNETA U RAZVOJU FRANŠIZNIH SISTEMA}

Apstrakt: Franšizing je poslovni format koji u savremenim uslovima poslovanja postaje globalni fenomen. Franšizni sistemi intenzivno koriste savremenu informacionu i komunikacionu tehnologiju (ICT) čime unapređuju komunikaciju između davaoca i korisnika franšize i obezbeđuju interakciju sa krajnjim korisnicima. Cilj istraživanja je da se na osnovu komparativne analize korišćenja ICT i Interneta $u$ razvijenim i manje razvijenim ekonomijama ukaže na značaj upotrebe savremene tehnologije $u$ franšiznim sistemima na globalnom nivou i na potrebu intenzivnijeg korišćenja ICT u našoj zemlji $i$ zemljama $u$ okruženju. Istraživanje je izvršeno putem sveobuhvatne on-lajn analize veb-sajtova franšiznih kompanija davaoca franšize. U radu se analizira da li postoji veza između povezivanja davaoca i korisnika franšize preko veb-sajta i broja datih franšiza. Korelaciona analiza je pokazala da postoji statistički značajna jaka pozitivna korelacija između upotrebe veb-sajta za povezivanje korisnika i davaoca franšize i broja franšiznih jedinica $u$ franšiznom sistemu. Može se zaključiti da manja upotreba savremene tehnologije i Interneta u nedovoljno razvijenim zemljama utiče na sporije širenje mreže franšiznih jedinica, nego u razvijenim zemljama u kojima je upotreba ICT i Interneta na mnogo višem nivou.

Ključne reči: franšizing, informaciono komunikaciona tehnologija (ICT), vebsajt, Internet, franšizne jedinice 